\title{
Evaluation of Sille Settlement in the Context of Ecological Tourizm
}

\section{Abstract}

Today, people have been seeking vacation in historical, cultural and natural environments besides coastal, sea and urban tourism, and they prefer different tourism activities. Tourism requests, focusing on traditional settlements with cultural and natural values, have caused the emergence of sustainable tourism approach. Ecological tourism, one of the sustainable tourism types, is used as sustainable development tool by protecting history, culture, and nature. Ecological tourism, which has minimal impact on the natural environment and has the least impact on ecological, and cultural heritage, contributes to the fields of tourism by protecting values, providing local economic benefits and eduction to the area where it is used.

Sille, located on the outskirts of Konya province in Turkey, has natural, historical and cultural values regarding alternative tourism. In this context, the study focuses on the evaluation of Sille as a new ecological tourism destination. The study was completed using survey, interview, photography and literature review. In the first part of the study, ecological tourism was defined. In the second part, natural, cultural and
Keywords: Rural development, ecological tourism, rural architecture, architecture, Sille

${ }^{*}$ Assist. Prof. Dr. Selcuk University, Department of Architecture, Konya, Turkey.

E-mail: deniz@selcuk.edu.tr 
architectural features of Sille were explained. In the third part, positive and negative sociocultural and architectural changes experienced recently in Sille were discussed. In conclusion, some suggestions were made within the context of ecological tourism for the development of Sille through tourism by preserving the values it already has and conveying these values to the future.

\section{INTRODUCTION}

Traditional urban textures, as the traces of past lives, are the places with their natural, historical, and cultural elements that have reached to modern day and where sustainable living should be established and preserved. Within the principle of sustainability, the preservation and survival of the old urban texture would be possible through the active use of all buildings within the framework of today's needs, their planning, and preserving them with their economic and social qualities (Lichfield, 1988).

The Venice Charter, which was adopted in 1964 and constitutes the international constitution of the protection issues, in its first article has carried the concept of "the monument to be preserved" to a much larger dimension from the concept of a monument and its surrounding. The first article states that "the concept of "historical monument" does not merely cover an architectural work, but it also covers an urban or rural settlement that witnesses a certain civilization, a significant development, and a historical event. The concept does not only comprise important art works but simpler works that gained cultural meaning in time." Thus, the concept of protection extended to include urban settlements with the necessary characteristics to be preserved, as well as an unchanged or slightly changed rural settlements (Url 1). Today, protection is perceived as protecting and sustaining the differences in all the values that the city has, along with its identity and natural environment (Meşhur, 1999).

Tourism is used as a positive power and development tool for traditional settlements and the preservation of cultural heritage and nature. Tourism is a sector that adds value to nature, culture, and history without requiring any additional costs (Kuşat, 2014). Tourism, an improvement tool for the developing countries, can be a major factor for development if it is well managed. Overexploitation, poor management, tourism-related construction in tourism areas threaten the unique structure, integrity, and existence of natural and cultural heritage (url 2). The concept of sustainability in tourism has been developed to gain economic benefits by protecting the natural, historical and socio-cultural values that are the source of tourism and transfer these values to future generations (Oral ve Şenbük, 1996). 
Within the framework of delivering values to future generations in sustainable tourism, the most important issues to be considered are to improve the living standards of the local people, functioning culture and functioning nature (Selimoğlu, 2004). Ecological tourism, one of the sustainable tourism types, has been identified as the most suitable tourism type for Sille, our study field, in the context of protecting natural and cultural sources (Weawer, 1999)

Sille settlement which has natural, historical and cultural structure is located on the outskirts of Konya in Turkey (Figure 1). Settlement of Sille, with its geography, history, population, living culture, and architecture, is one of our cultural heritage values that needs to be protected, and its lost traditions need to be regained and transferred to the future generations. Today, Sille settlement is under protection, and it is planned that the settlement which has conservation plan would be developed with tourism. The opening of our cultural heritage to the tourism without using the right method causes to the weariness of common values. It is seen that the most accurate tourism route that would enable Sille's development by considering its values would be ecologic tourism.

The purpose of this study is to examine the traditional settlement of Sille and to lead it in the context of ecological tourism. For this reason, ecological tourism content will be examined in the first section of the paper; the second part will be about the natural, historical, socio-cultural and architectural features of Sille as a traditional urban settlement which can be a subject of ecological tourism, and the third part includes information about the studies on transition to protected tourism. The final part has a conclusion and some suggestions. The study was completed using survey, interview, photography and literature review.
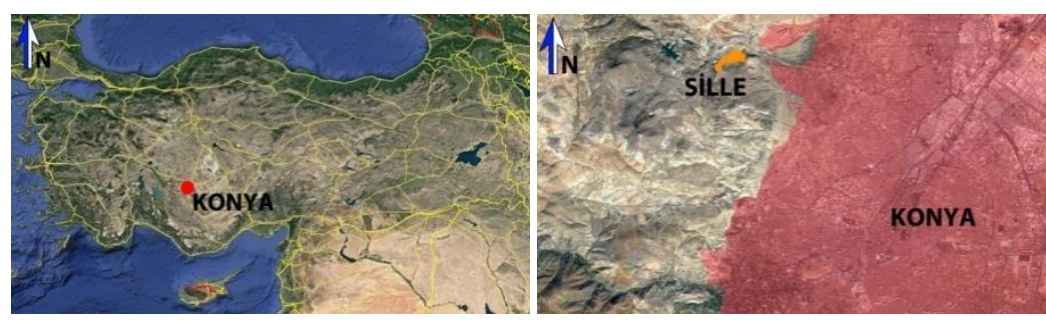

\section{ECOLOGICAL TOURISM}

In time, mass tourism (urban and coastal tourism) had negative impacts on natural and cultural sources. Ecological tourism developed in the 1980s as a reaction to the impact of endangering the tourism areas and destroying them (Erdoğan, 2003). The United Nations Commission on Sustainable Development declared 2002 as the "International Year of Ecotourism," and in
Figure 1. Location of Sille (Google Earth, Date: 05.05.2017) 
May of the same year, all the countries joined World Ecotourism Summit in Quebec, Canada. United under the same definition. Accordingly, ecotourism was defined as "An approach and an attitude for securing the sustainability of natural resources on earth while providing support for the economic development of local communities and protecting their social and cultural integrities" (url 3). In short, ecological tourism, which is used as ecotourism, includes rural and cultural tourism elements and is known as the most suitable type of tourism that can be developed in natural and cultural areas that need to be protected (Kaypak, 2010). Ecotourism is a type of tourism that is based on the principle of acting with a responsibility to avoid negative impacts on the environment that connect natural and cultural environment with tourism (Turizm Bakanlığı, 1999). Ecotourism that has the least impact on natural and cultural heritage and contributes to the preservation of their values is more advantageous when compared to other tourism types (Bakırcl, 2002). Ecotourism is based on combining economic development with the purposes for protection (Kaypak, 2012).

In ecotourism, the principle of sustainability of local the cultures is important. Material and spiritual values of the local culture should be respected. It is necessary to treat and respect the local cultural artifacts, to support their protection, and to prefer and support the accommodation facilities which serve authentic structures instead of modern architectural products which do not match the local art. In the regions where the local cultures are lived without corrupting moral values, tourist groups must treat these values with respect (to care for costumes, to respect religious and traditional values, to participate local eating and drinking ceremonies, enjoy local entertainment as much as possible ).

In ecotourism, it is necessary for the local communities benefits from tourism activities and obtain financial share from touristic activities. For this reason, it is necessary for small regional agencies, rather than large international tour operators, to take part in ecotourism activity. The tour needs should be provided from the region and benefit to the region. Training, workshops, and briefings should be given to local managers and the regional community about the types of ecotourism, and methods and support should be provided for developing eco-accommodation opportunities (Url 3).

Ecotourists are people who are generally from middle or upperincome groups, who love nature and participation, and people who act with the spirit of sensitivity (Kahraman ve Türkay, 2004). 
Evaluation of Sille Settlement in the Context of Ecological Tourizm

Ecotourists also make a contribution to the local people's wealth by creating employment and financial tools (Kaypak, 2012)

\section{SILLLE SETTLEMENT}

\subsection{Geography, History and Population}

Sille, $12 \mathrm{~km}$ North-west of Konya in Turkey, is a small town located on two slopes of a deep and narrow valley in the east-west direction. (Figure 1-3)
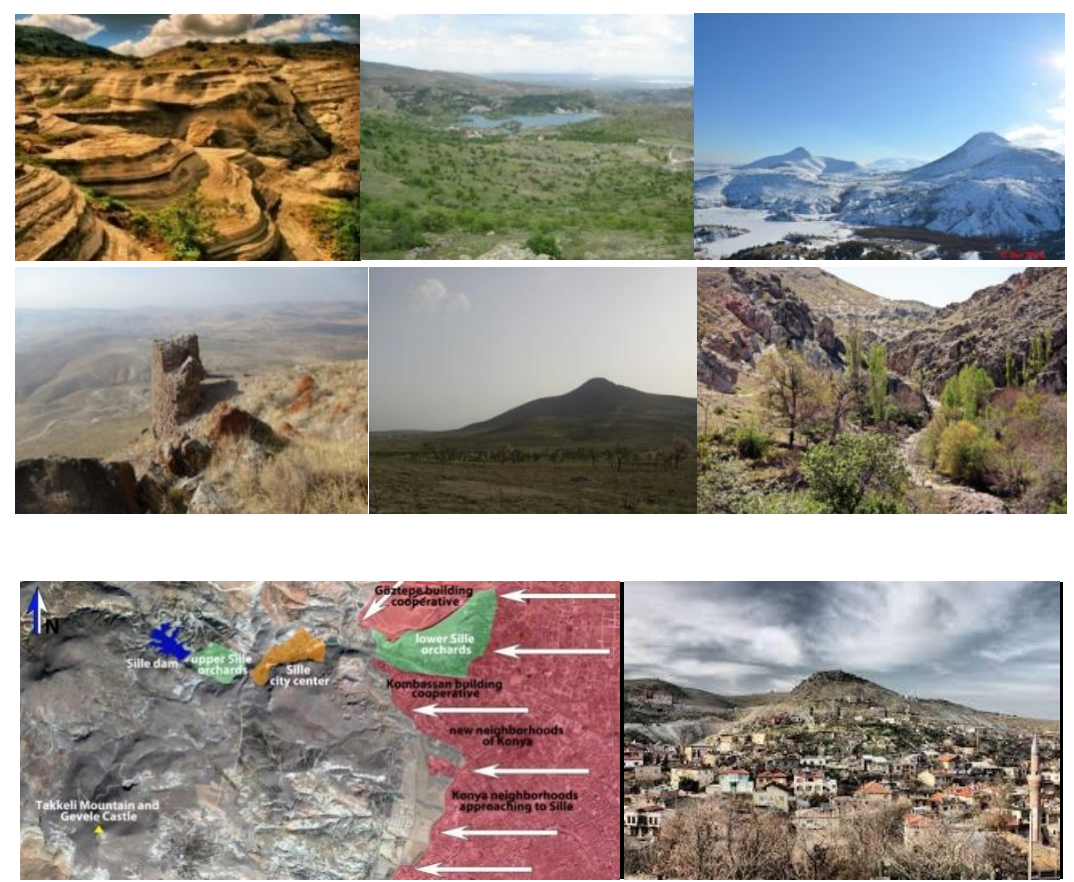

The seasonal waterways around Sille are characterized by floods with dry streams and water flows during rainy seasons (Tapur, 2013). The Sille Creek, which flows from the west to the east, divides Sille into two parts (Figure 4). Due to the irregular flow regime and flood hazard of Sille creek, the Sille Dam was built in the west of the settlement in 1961.

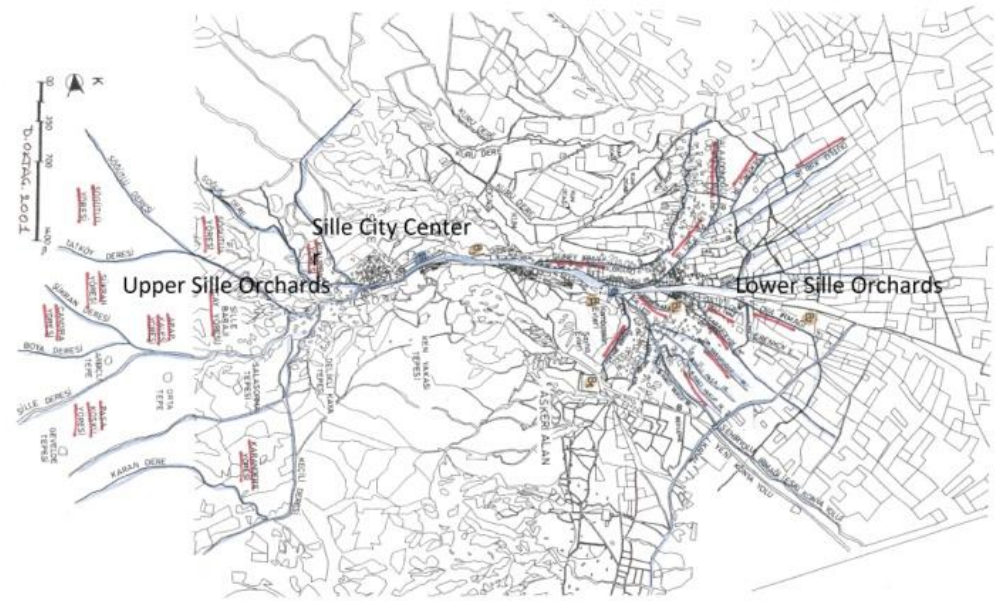

Figure 2.Natural formations around Sille, Geleve Fortress and Sille Dam (Google Earth İmages, Date: 05.05.2017)

Figure 3. Sille satellite view and city view (Processed on Google Earth image. Date: 05.05.2017)
Figure 4. Map showing Sille and its surroundings (Author, 2001) 
An active fault line named as Konya fault is situated it the southeast direction of Sille. In the south, there are volcanic rocks (andesite, trachyte, granite) formed in Miocene (Biricik, 19981999). Sille Stone, with its slightly pinkish color, is used in many buildings in Sille and Konya. Due to its easy workability, it has been preferred as a flooring, covering, paving stone, due to its resistance to the heat, it has been used in brick tile factories, lime quarries, and furnace construction

Oak and pine trees are seen in the mountainous-plateau regions of Sille, while willow, populus and fruit trees are observed at the valley bottom (Tapur, 2009). Since Sille has a continental climate and located in a valley, winters are warmer, and summers are cooler than Konya (Aklanoğlu, 2009)

\section{History}

Settelement had the names of "Silena" by Phrygians period (Baştak, 1938)“Sullata" or "Silata" by Greeks (Bildirici, 1994), "Su Dirhemi" in Ottoman period (Aköz ve Ürekli, 1997)and finally "Sille" in Turkish Republic.

According to the archeological excavations around Sille, historical ruins have been found in Tatköy from the Neolithic Period and in Gevela Castle from the Iron Age (B.C. 1000) (Bahar, 1994). The town has been used as a settlement since the Azianic, Hittite, Phrygian, Greek, Roman, Byzantine, Seljukian and Ottoman periods, (Baştak, 1938) (Figure 5). Rock-carved places (churches, tombs, and dwellings) that bear traces of Roman and Byzantine eras can be seen in Sille today (Konyalı, 1964). Sille is on the Silk and Spice Road routes, which is important from the 2nd century to the 1800s. During the Christian period, it has become one of the visiting places of holy pilgrimage routes (Sarıköse, 2009) (Figure $5)$.

Figure 5. Sille from Getrude Bell's camera in 1905 (url 4, 05.05.2017)

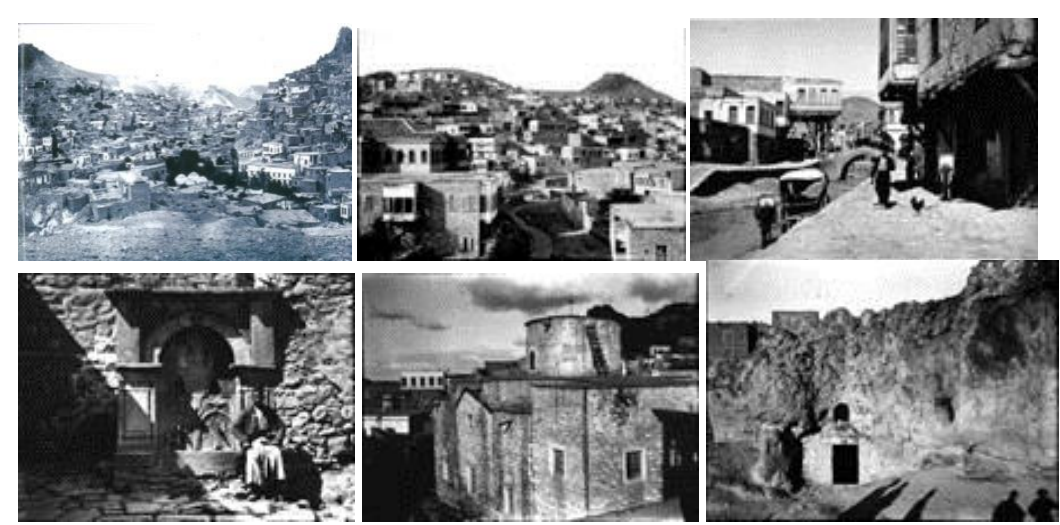

Population Features

When the Turks came to Anatolia, they had encountered Turkish elements such as Bulgarian, Hazar, Pechenek, Uz, Kuman and Avar who accepted Christianity, which was introduced to the region by 
the Byzantines. According to 1300/1882 Almanac of Konya, among 5500 households the Muslim population was 6296, and the non-Muslim population was 1349 . Totally 7645 people lived in the town (Aköz ve Ürekli, 1997). According to the Population Exchange in 1926, the Christians were replaced with the Muslims from Balkans. Until the exchange, the Muslims and Christians have lived together fraternally, confidently and permissively under the tolerance of administration without presenting any discrimination. Sille has reached today by building commercial and cultural links with Konya (Dülgerler, 2000).

\section{Livelihood Resources}

Citizens of Sille became famous with their mastership in construction, especially with their mastership in stone walls. Because of its alluvial soils, soil manual labor has developed in Sille. At the workshops in Sille, soil products such as tiles, bricks, floor furnaces, pitchers, earthenware jars, and pots have been processed (Nas, 2014). Agriculture and animal breeding remained at the level of meeting the requirements of the community.

Weaving, which had its origins in the Phrygian period, has always had its place in daily lives of the community. Carpets that were colored with "cehri" plant and root plants, has a special place in the world known as "Sille Carpet Business" (Sarıköse, 2008, Akan and Hidayetoğlu, 2014). In Sille, production of candles from suets is a traditional art that has been carried out for centuries (Özönder, 1998)

\subsection{Social Life Culture and Traditions}

People in Sille live in the city center during the winter months and in orchards during the summer months as most of the Anatolian people do. Residents of Sille who had homes or cottages in the orchard would move to the orchard during Hidrellez (old Turkish celebration of spring), and they would move to their homes in Sille at the end of October. The family members migrate to their winter house with all the household goods used in the orchard house such as bundles, even the demountable wooden goods, and the products obtained from the orchard, large earthenware jars, and animals. The products of the orchard, foods, firewoods, drieddung blocks will provide a comfortable life in the winter season (Oktaç, 2001)

The water regime and the soil structure of Sille and the regional tradition of using grape products and molasses instead of sugar have resulted in producing only grape which is named as dimlit, gut, fox's tail, smocked, aladiriz, dark girl, camel eye, germe, and white grape. (Tapur, 2014). ). Grape molasses, molasses products, vine, and vinegar are made of grape syrup (Oktaç, 2001) 
Sille is also famous for its entertainments named as "Barana, Ahek, Hıdırellez, Gereğiler (Taking grape to the Reverend)" (Kılıçaslan, 2009, Kapar, 2014). All the citizens living in Sille are involved in these spontaneous entertainments, and all activities are traditionally determined (Bağcl, 2009)

\section{SİLLE SETTLEMENT CHARACTERISTICS}

Sille is located in the northwest of Konya in Turkey. Entrance from Konya is in the east of the settlement (Figure 1). Sille is located on the southern slopes of the region at the northern part of Sille River (Figure 6). There are rock cave areas above the Dam road on the northern skirts of the valley (Figure 7). The settlement spreads along the creek along the eastern, western axis, adapting to the dam, narrows on the sloping ground on the north and south axis. For this reason, the main roads follow the river. Most important of these roads are Hükümet Main Street passing from the north of the river and Baraj Main Street passing from the south of the river. The settlement is mostly dense around Hacı Ali Ağa Street and Karataş Main Streets. Roads that are parallel to the river and the slope are connected to the upper roads with short roads which are slopy or have steps. Road coating is made of Stone, and water is discharged from the middle of the road. At the small squares where the streets cross, fountains and furnaces with their covered tops can be seen.

Figure 6. Sille urban texture (url 6)
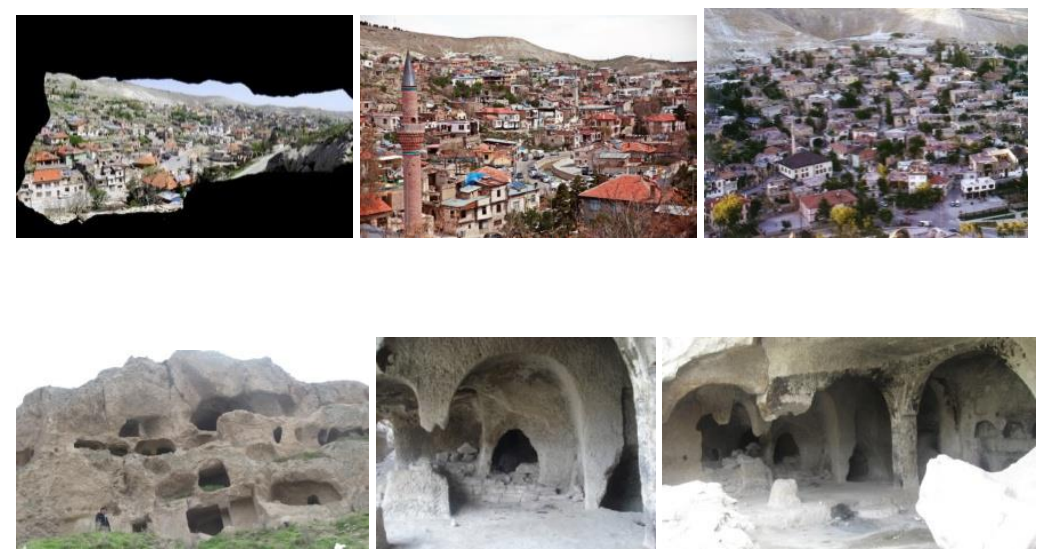

Figure 7. Rock carving spaces (Author's Personal Archive-2012)

The southern and northern parts of the river are combined with bridges. The oldest one is "Stone Bridge" while wooden, concrete and iron bridges are also built.

The settlement area at the southern part of the rivers and especially at the southwest region where Aya Eleni church is situated is a region known as Subaşı Quarter. This is a region where houses and work places of the non-Muslim community are located. Work places, shops, and stores, called "Karhane," are located within the residential structure as one-storey the front side of which was covered with wooden or metal cover. 
While mosques were situated at different places within the texture, churches were generally situated on the west side of settlement area. Its mosques were Kurtuluş (Mormi) Mosque, Şubaşı Mosque, Kayabaşı (Mezar yakası Mosque), Orta Mahalle Mosque, Ak Mosque, Karataş Mosque and Çay Mosque. Around Sille, there are many living spaces and churches that were made from rock. These are situated at the northern part of the mountainous area at the southern side of Sille River. Bela Hovath stated that in the year 1913, there were sixty churches in Sille. Among these, there are Akmanastır, Aya Eleni (Big) Church, Çevrikler Mezarlık Arkası (Behind cemetery), Hıdırellez Church (At the Greek Cemetery), Aşağı Church, and Kızıl Church.

None of the structures mentioned in the almanac such as Sille Caravansary and inns survived today (Özönder, 1998). One of the two Turkish baths (hammam), called Hacı Ali Ağa Hammam is situated at the entrance of Konya road. Şubaşı hammam is situated within the quarter which is known by its name.

Cemeteries that are situated in Sille are Ak Mahalle Yeni Cemetery (Aşağı Cemetery), Sille Martyr's Memorial (Garipler Cemetery), Ak Mahalle Eski Cemetery, Subaşı -Gölbaşı Cemetery, Mormi Cemetery, Karataş Cemetery, Şubaşı / Burial Area at Karhane Mosque, Gayrımüslim Cemetery (Sarıköse, 2008, Işık, 2014)).

\subsection{Traditional Houses}

Residences and other structures form a texture with their terraces without disrupting the slope of the land. The appearance of the settlement texture consists of prismatic structures that are aligned side by side, rising with the elevation angle of the slope. The adjoining dwellings are overlaid on the street with closed or open flats (Figure 8-9-10). Constructions do not interfere with each other in the direction of the sun, the wind as well as the landscape (Figure 6). They have avoided facing to the courtyard of each other or the inside of a flat. However, there are doors of sincerity and friendship, which are opened from the storehouse, the garden, even the houses (the neighboring house to the neighboring house) as a work of beautiful, neighborly relations between them. 
Figure 8. Slope placement of Sille residence plans in plan level (The Kamberoğlu and his son's Houses) (The drawing from Architect Argun Dağıstanlı has been improved.)

Figure 9. The fotograph of given the plan area (Personal Archive, 2012).

Figure 10. Street and housing samples (Personal Archive, 2012).
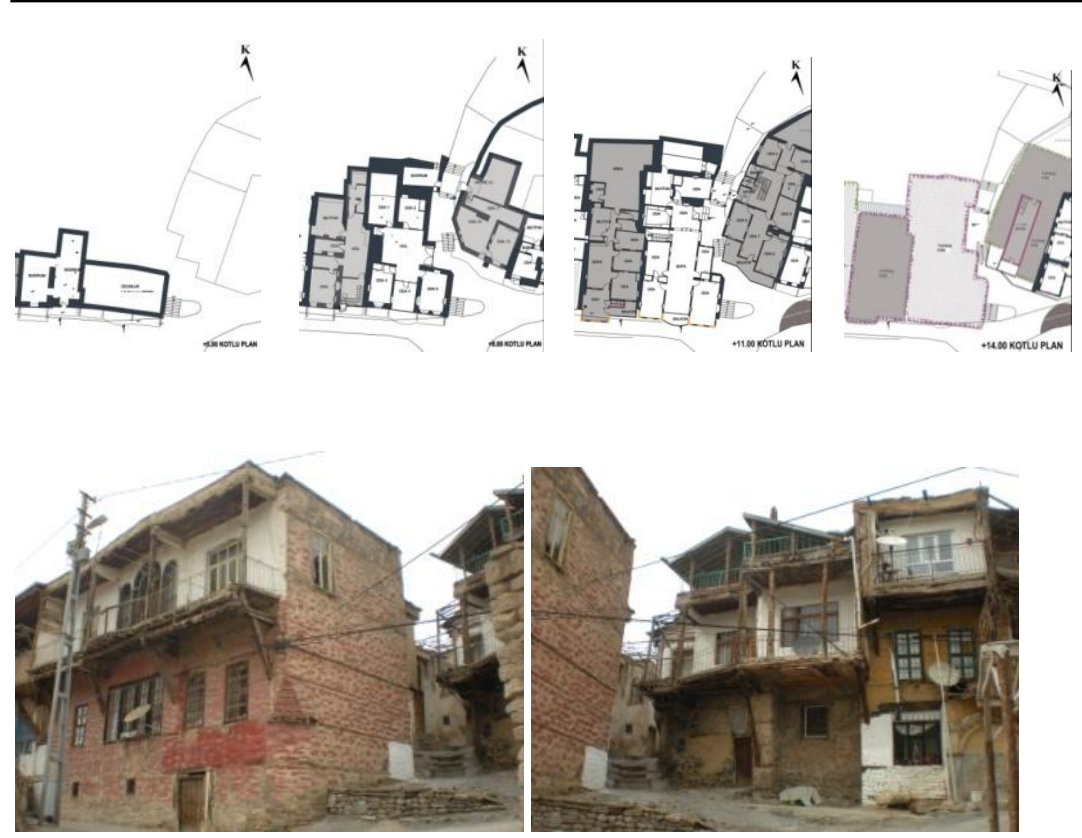

The top of some narrow streets was closed and they were turned into rooms. These spaces which were named as "Hanay", made the houses look as if they were joined from outside (Özönder, 1998, Karpuz et al., 2013).

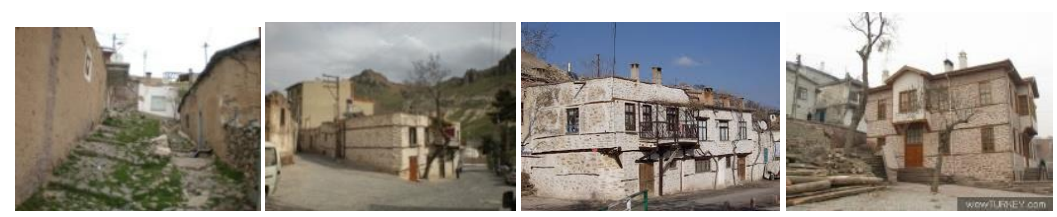

Mostly the houses have two floors above basement. In the basement floors, there are separate entrance doors to the stables from different levels. While entering the stable from the lower road, the first slope and the second flats are entered from the level of the rising perpendicular slope. While the ground floor and the first floor are connected with stairs from inside, entrance to the floors could be made from the street with upper level. Some housing and service areas are accessed by passing a perched guard behind the stone walls when viewed from the street. When the structure of Sille is viewed from the opposite direction, the trees rising from the yards between the buildings and grapevines surrounding the buildings from the front facades are seen. At the entrance of housings that don't have yards or gardens, flowers and grapevines which are raised in vases climb over the fronts of houses and add a green feature to the texture.

The ground floor of the houses is accessed from the street by using a two-wing wooden door. There is a window over this main entrance door to bring light in. The entrance is usually a dimly lit floor with a stone floor and a small water well and carpet loom. Toilet and shower areas are situated on the ground floor at the wooden section of the stony entrance. The space accessed by going up a few steps from the ground floor is an area reserved for 
male quests. This place, a window of which overlooks to the road and the other window looks at the stony ground flor, is used as a winter room in many houses because it is sheltered. Because of the adjacent structures of the houses, Sille had wedged into the rectangular plan home plan (Figure 8). Therefore, a window looking at the stony ground was opened to receive light and air to these dark places.

The first flor is accessed by using separate wooden stairs. The kitchen which is situated in staircase provides easy service opportunity to the first and second floors. "Bievi" space is accessed from the kitchen is used as a cellar. Here food has been stored in jars and glazed pots. The space does not have windows, or it is cooled by a window facing to the north. The space completing the relation of 'Bievi' and the kitchen is "Bush area" where the bush required for kitchen furnace is stored.

Kitchen, hand washing water and toilet water and shower waters are discharged to separate dirty water jars in the garden or in the basement to avoid mixing each other.

The first floor above the ground floor is the area from where the planning scheme of the house could be viewed. Each house in Sille has a different plan scheme that is designed as per different land conditions and requirements of each house. Sille houses have a sofa plan type, which is one of the traditional Turkish home types. In some of the houses in Sille, sofa area was kept bigger than in samples in Konya, and passage to the rooms and other functional spaces could be made from this area. In some examples, the rectangular planned sofa is perceived from the front in the form of openings (balconies) called "front roof."

Rooms are very spacious with a width of $3.0-3.5 \mathrm{~m}$ and a length of 5.0-7.0 m. There is a cedar in front of the window on the front, and a wooden cabinet consisting of a bathing cubicle, carpets, and flowers on the wall between the other room.Flower beds which are also placed on the sofa walls are wood carved niches. Room walls are furnished with cupboards with wooden covers. For the ceilings, In the sofa and rooms "round wooden beams" are used, or wooden coating is done.

Rooms were given names according to their functions. Room in which the floor furnace is placed is named as "winter house," dark room is named as "chest room" and a room with grape clusters is named as "grape room" (Özönder, 1998)

Most important ornament of the housings is stone material that is the main structure component. Door handles, corner chamfers and cubical mass are among the aesthetical characteristics. The 
room has a simple touch with wooden cupboard, flower beds, and the other features.

The basic material of housings is Sille stone. Stone structures have lime sutures. Wooden parts made from pine, juniper, and poplar trees are used in wooden joinery, columns and in room beams. Mudbrick material is seen as filling material on the timber-work walls.

Basic wall thicknesses in the houses are between 70-80 cm and the thicknesses on upper floor walls is between $60-65 \mathrm{~cm}$ and on the walls, a special system, named as "bağdadi - dolmagöz," has been used. Stone walls have been made stronger by using wooden stretchers. Wooden pillars can be seen on cellar floors and sometimes on upper floors. These pillars have wooden beams, and they provide support for the ceilings.

Roofs are flat soil roofs. After the wicker that is placed on wooden beams, thin tree branches are put, and thatch and sedges are also placed. Afer the mudbrick, arid soil with purple color is placed on top, and the roof structure is completed.

\subsection{Properties of Sille Orchard Settlement}

The roads in Sille's orchard settlements have been opened parallel to Sille Stream and its narrow branches (Figure 4). The pedestrian paths near the orchards have been leveled by man power and hardened with sands brought by the stream (Figure 11). In general, the orchards settled on the inclined lands extending from west to east are quadrilateral shaped fields side by side and creating a harmony between channels and roads.

Although there were shacks (tol) and orchard houses especially belonging to the non-Muslim people before the Exchange, they were all destroyed and disappeared due to lack of care after the Exchange. The shacks have been constructed at the secluded orchard sections for people and animals to protect themselves from extreme weather conditions. Shacks (tol) are small-size stone huts whose top and three sides are closed while the front side is left open. Closing the front side, the shack becomes a room or a barn. Sometimes these two units (room and barn) are constructed together side by side or as two floors; one room at the top, the barn at the bottom floor (Figure 12-13) (Oktaç, 2001) 

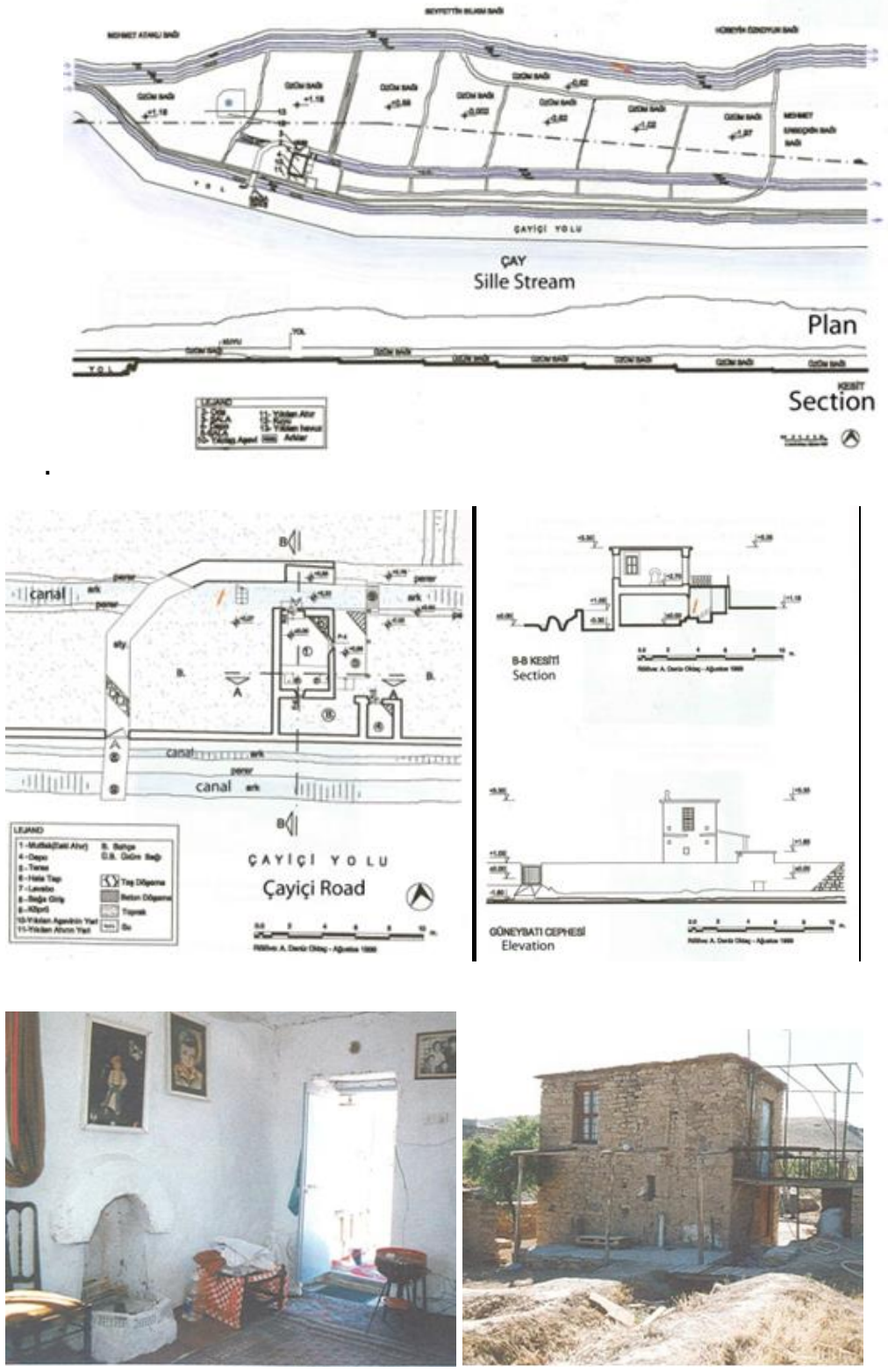

Figure 11. A Sille Orchard Plan (Yanartaş Orchard) (Author, 2001)

Figure12. Yanartaş shack sample in Sille Orchards (plan, section and facet) (Author, 2001)

Figure 13. Yanartaş shack sample in Sille Orchards (Author, 2001)

\section{CHANGES IN SILLLE AND TOURISTIC ACTIVITIES}

\subsection{Changes seen in sociocultural and economical life:}

While Sille was a municipality with a population of 3600 people and seven quarters till 1999, it was connected to Konya Municipality as two quarters in 1999. These are Ak Quarter (Aşağl Quarter, Kayabaşı, Camii Kebir, Çeşme-i Kebir Quarters) andSubaşı Quarter. (Kurtuluş, Orta Quarter and Karataş Quarters).In the elections of 2014, all of the quarters were combined under the quarter named as Subaşı.

Changes experienced in Sille: At the beginning of twentieth century at the Ottoman period, it was a settlement area having a population of 18.000 and a municipality, where commerce gained importance with nearly 300 stores. The first change was seen in 
the population as the non-Muslim community was removed from Sille and the Muslim population from Balkans was brought here. It could not be possible to fill the space of the non-Muslim community that was dealing with trade, jewelry, and other forms of art while making production and holding capital in their hands. Today elderly citizens of Sille remember their non-Muslim neighbors with longing because it has been difficult for them to unite with the population having a different culture. Furthermore, the necessary measures to enable trade and traditional arts to survive were also not taken. Sille has undergone a socioeconomic change and a great convulsion (Özönder, 1998)

After the exchange, the second change in population was lived through in the 1970s with the influence of industrialization in the country and the related urbanization. The residents of Sille sold their houses to the villagers of Tepeköy and Sulutas and moved from Sille to Konya where they settled. These two population changes have altered sociocultural and economical life in Sille. In Sille, people with different cultures began to live, and these people did not know the former sociocultural life, grapes and techniques to use them. Activities such as harvest feasts, Barana-Harmony remained in the memories of the elderly citizens of Sille, and these activities are not known by the current community. Local terms have been forgotten.

The current community in Sille has low-income level, and they work at jobs that they can find in Konya. There are few numbers of construction masters and vine growers. The community in Sille is not trained about the developing tourism sector. However, a few numbers of enterprises such as Sille Konak Restaurant, Boutique Hotel, and Kemeraltı Cafe are operated by the residents of Sille.

Existing educational institutions are an elementary school, a private school at the exit location of Sille towards Konya road, and Kent Workshop aiming to raise construction masters. Kent Workshop has not beeen used in line with its purpose, and it is used as a training center by KOMEK (Konya Vocational Courses). At the Sille Kent Workshop, which is currently closed, training were given on carpet making, paper marbling, folkloric baby doll making, mat and ceramic shaping and mother of pearl inlaid.

Among the traditional art forms carpet making, jewelry, weaving, candle making have been forgotten, and stone mastership works began to be reduced. Masters dealing with soil works (pots, crockeys, etc.) got older. The final remaining workshop is striving to continue this occupation. The master of the workshop states that there are no people interested in learning the profession. In candle stores, candles that are imported from outside are sold. 
The residents of Sille are working in Konya as staff in trade and other occupational areas.

\subsection{Architectural change, protection and tourism activities:}

As the community of Sille lost their sociocultural and economic values, many structures were abandoned. The reason for collapsing of a thousand year old structures in Sille, which is known to be close to a fault line, is not earthquakes by their abandonment. When the old and new pictures are viewed, it is seen that the quarter near Karataş mosque has completely disappeared and that Karataş Mosque has remained alone. It is observed that many structures within the settlement structure of Sille are not in their places (Figure 14). The residents of Sille say that those having houses in high altitudes abandoned their homes and bought houses near the river. Houses which are collapsed as they were abandoned, stores that were closed or turned into houses, monuments not taken care of, have caused the city texture to become unrecognizable. Reinforced concrete structures and flat roofs were covered with wooden structures change the silhouette. In short, as Sille came from twentieth century to this time, it had an appearance that looked like a ruin. While the situation is like this, it is pleasing to see that many structures like mosques, churches, rocky spaces, Turkish baths (hamam) and fountains remain. While the registration works relating to cave engraving spaces continue to be processed, Konya Directorate of Museum and Municipality are carrying out the cleaning works.

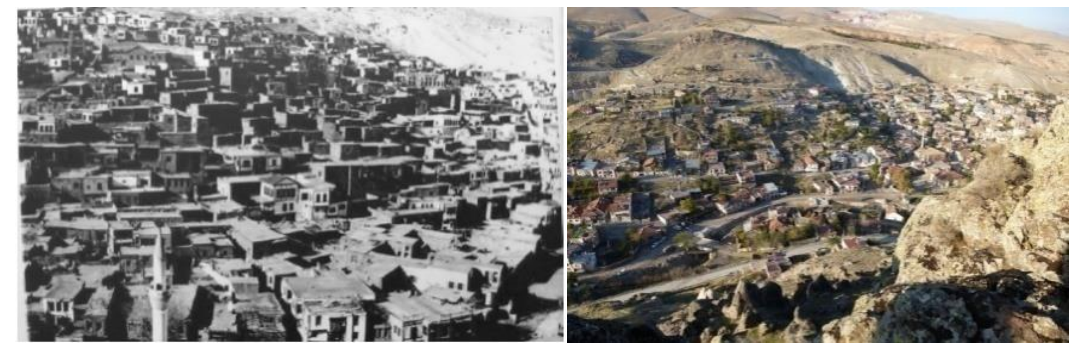

In Sille, viticulture is under threat as the orchard are abandoned due to orchard diseases, lack of water, structuring requests. Even if it is not outside the protection area, there are no structure works at the moment. Vineyards comprise of agricultural lands where requirements of land owners are met by using new irrigation techniques, old and new orchard houses. On the other hand, as there are high floor apartments being built in the vicinity of Sille, it is seen that Sille and its orchard are under threat (Figure 3).

After Sille was announced as an urban and archeological protection area in 1995, Sille Municipality has aimed to open Sille to tourism as a development model starting from 1998. Tourism activities which started with stream improvement and continued with a restoration of Hacı Ali Hammam and turning it into an
Figure 14. Differences between old and new Sille (Bell, 1905 -url 4 and Author's Personal Archive- 2012) 
ethnography museum are still continued. All of the mosques and churches were restored. On Hükümet Main Street and Hacı Ali Street, works relating to facade arrangement and stone coating on floors were carried out. Restoration and reconstruction works are carried out on structures that are expropriated by the state or owned by private sector. At the entrance of Konya on the area that is situated in the southern part of the bridge, Municipality Hotel is being built. Besides Selçuklu Municipality Sille Art Gallery, a private Photography Art Center is also opened.

It is seen that some touristic enterprises are opened in Sille. The majority of places where touristic objects are sold, café and restaurants, and boutique hotels are operated by exploiters coming from outside of Sille.

While local materials and construction techniques are used in the restoration of registered structures, reinforced concrete works are applied in reconstruction and newly established structures. It is seen that in Sille, relevant institutions dealing with construction have doubts about the usage of local materials and construction techniques, and it is seen that reinforced concrete structures are implemented widely.

The touristic activity observed on Hükümet Main Street is not seen on the upper street, and the daily life is continuing there away from tourism. Restorations and works for strengthening the streets are carried out with the images of bedraggled street. In 2001 the Sille Conservation Plan introduced and enacted (Figure 15). After this date, the Sille Commission, which was founded in Selçuklu Municipality in 2016, started to work.

Figure 15. Sille Conservation Plan

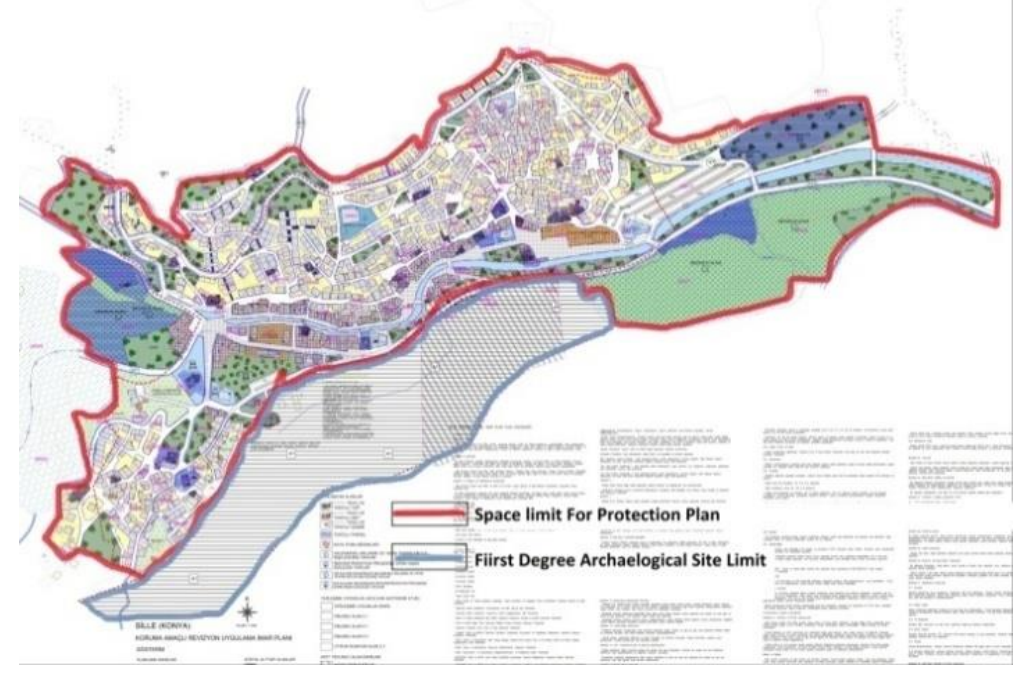




\section{CONCLUSION:}

Tourism is used as a positive power and a development tool for the protection of the culture heritage, traditional settlements, and the nature. Ecological tourism, in which nature conservation creates the least impact on the natural environment, contributes to the field of tourism on the preservation of values that have the least impact on ecological and cultural heritage, local economic benefits and education.

The Sille settlement, located on the outskirts of Konya province in Turkey, with a cultural heritage of thousands of years has a significant tourism potential regarding geography, nature, history, especially as a tolerance center where different religions are blended, its unique socio-cultural values, and with the attraction of urban and orchard settlements. Changes in population structure and sociocultural life have led to the loss of cultural heritage values. Today, in Sille, which has lost its traditional handicrafts and traditions, a different lifestyle has been experienced that creates a different social texture.

Sille which was taken under protection at a late date after losing many values in the traditional sense, has been targeted to development through tourism since 1998. For this purpose, the improvement works in the physical structure, restorations, street health works stand side by side with the poor houses.

The improving works gave their fruit and tourism has gained momentum in the last two years. In Sille, tourism enterprises are mainly opened by foreign capital and tenants. Local people cannot afford to run tourism enterprises. Local awareness and development initiatives are not at the expected level. Religious values, Nature, and agriculture-related activities are not organized.

Sille, as a destination attraction center, is a settlement with ecological tourism values. It should be managed with ecological tourism methods to protect and transfer the natural and cultural values to the future generations. For this purpose, the following recommendations are foreseen:

\section{Recommendations regarding the physical space and its protection:}

* It should be avoided for tourism to give harm to cultural heritage under the purpose of achieving development. With the help of local planning and conservation work, the original silhouette has to be preserved, and the proper restorations of traditional houses should be made, and these structures should have new functions such as pension, hotel, culture and arts centers, museums, local food and handicrafts businesses. 
* In the empty areas that disturb the silhouette, the construction of the new building should not be allowed in the historic surroundings, and apart from this, there should not be any new constructions especially for accommodation. New standards should be introduced regarding plates creating visual pollution, mechanical facilities, and the existing settlement.

*Ministry of Culture conservation boards and local governments should guide and support restoration, reconstruction and use of traditional construction techniques and materials in new constructions. The Sille Town Workshop should be a local center providing material and technical support as well as being the center of training master craftsmen.

* The orchards outside the protected area, which are natural, historic, and cultural values, should be protected as agricultural land and should be evaluated as agricultural tourism and local products should be produced for nutrition.

\section{Recommendations regarding Management Planning and Training the Community}

* At each step of Sille management planning, ecological tourism and natural and cultural values should be protected, and local development should be promoted. Local governments, public, non-governmental organizations, technical teams, universities should work together in the sustainable management plan.

*International quality standards and physical environment regulations, transport, communication, electricity and health infrastructures should be completed

* Participants should put their efforts to attract qualified, educated and conscious tourists. Incoming tourists and residents should be informed about Sille's heritage values, their use, and preservation. To support local development, public training on tourism services and businesses should be provided.

* Any kind of technical and economic support should be given to the local people for their participation in tourism (tour agency, guidance, education, tourism operation, etc.). The citizens of Sille, who has settled mostly in Konya, should be granted privileges in tourism support to revive the old life culture (collaboration, local terms, dining culture, entertainment activities like barana, gereğiler, hıdrellez) and agricultural traditions (viticulture, usage of products) that Sille has.

*Relations with universities should be developed, and the universities should become centers of interest in areas such as art, culture, conservation, and tourism related to Sille's sustainability. 
Sille ecotourism should work with diversified tourism throughout the year instead of mass tourism.

* Advertisements should be given through international and national agencies, regional promotional films, touristic introduction booklets, bureaus, guidance services, and website installation.

\section{Recommendations regarding tourism activities}

*Support for training, space, and economy should be given for the promotion and marketing of traditional arts. The development of traditional arts (soil works, candle works, jewelry, weaving, carpet making, music), and the design of tourist products, which are unique brand values, should be supported by university and local vocational training courses.

* Besides natural and cultural tourism, Sille also has values regarding belief and agricultural tourism, and these potentials should also be used. Different tour routes should be established such as cultural route comprising Sille cave and urban settlements, nature route comprising vineyard areas, climbing route comprising Takkeli Mountain-Gevele Castle, and religious route comprising spaces, caves, and structures which are especially important for the Christians. On the tour routes, facilities should be established to meet the needs of the visitors such as resting areas and food courts.

*Orchard tradition of Sille and grapery should be supported, and for the interested tourists entertainment culture at the orchard during maintenance, harvesting and post-harvesting should be revived. Grape production should be developed again, and besides fresh grapes, traditional grape products should be produced for tourism purpose again.

\section{REFERENCES}

Akan, M., Hidayetoğlu, M. (2014).“Sille Halıcılığı ve Bugünkü Durumunun Değerlendirilmesi", I. Ulusal Sille Sempozyumu 26-27 Eylül, 2013, s. 197-208, Konya.

Aklanoğlu, F., 2009, Geleneksel Yerleşmelerin Sürdürülebilirliği Ve Ekolojik Tasarım: Konya-Sille Örneği, Ankara Üniversitesi Fen Bilimleri Enstitüsü, Ankara.

Aköz, A. ve Ürekli, B., 1997, Tarihi Seyir İçerisinde Sille'de (Konya) Müslim- Gayrı-ı Müslim Yerleșimi, Ata Dergisi, VII, 194195.

Bağcl, Ö. F., 2009, Barana Kültürü, 5000 Yıllık Kültür Vadisi Sille, 3, 20-23.

Bahar, H., 1994, Takkeli Dağ (Kevela Kalesi) ve Konya Tarihi Bakımından Önemi, Selçuk Üniversitesi Sosyal Bilimler Enstitüsü Dergisi, 3, 314. 
Bakırcl, M., 2002, Ekoturizm. Ekoturizm", İkinci Turizm Şurası. Ankara, Turizm Bakanlığı.

Baştak, N. F., 1938, Sille, Konya, Birinci-İkinci Kanun, p. 947-970.

Bildirici, M. (1994) Tarihi Su Yapıları (Konya, Karaman, Niğde, Aksaray), DSİ. Genel Müdürlüğü Yayınları, Ankara, s. 181.

Biricik, A. S., 1998-1999, Sille Çayı Havzası, Marmara Coğrafya Dergisi, 2, 33-55.

Dülgerler, O. N., 2000, İnanç Turizminin Merkezi ve 5000 Ylllık Otantik Kent Sille, Selçuklu, 26, 10.

Erdoğan, N., 2003, Çevre ve (Eko)Turizm, Ankara, Erk Yayınları

Işık, A. (2014)."Geçmişten Günümüze Sille Mezarlıkları ve Buralardaki Osmanlı Dönemi Mezar Taşlarından Bazı Örnekler", I. Ulusal Sille Sempozyumu 26-27 Eylül, 2013, s. 385-414, Konya.

Kahraman, N. ve Türkay, O., 2004, Turizm ve Çevre, Ankara, Detay Yayıncillk

Kapar, M.A. (2014). “Sille'de Gelenek ve Görenekler”, I. Ulusal Sille Sempozyumu 26-27 Eylül, 2013, s. 91-98, Konya.

Karpuz, H., Aygör, E. (2014). "Sille Evleri", I. Ulusal Sile Sempozyumu26-27 Eylül, 2013, s. 113-155, Konya.

Kaypak, Ş., 2010, Ekolojik Turizmin Sürdürülebilirliği, Alanya İsletme Fakültesi Dergisi, 2 (2), 93-114.

Kaypak, Ş., 2012, Ekolojik Turizm ve Sürdürülebilir Kırsal Kalkınma, KMÜ Sosyal ve Ekonomik Araştırmalar Dergisi, 14 (22), 11-29.

Kılıçaslan, M., 2009, Sille'de Komşuluk İlişkileri, 5000 Yıllık Kültür Vadisi Sille, 3, 17.

Konyalı, İ. H., 1964, Abideleri ve Kitabeleri ile Konya Tarihi, Konya, Yeni Kitap Basımevi

Kuşat, N., 2014, Rural Tourısm As An Alternatıve For Sustaınable Rural Development And Its Applicability İn Turkey, The International Journal of Economic and Social Research, 10 (10), 65-88.

Lichfield, N. (1988). Economics in Urban Conservation. Cambridge University Press, England

Meşhur, M. Ç., 1999, Tarihi Çevrelerin Korunması Sürecinde Yeni Yaklaşımlar: Amasya Kenti Örneği, Selçuk Üniversitesi Fen Bilimleri Enstitüsü, Konya.

Nas, E., 2014, Sille Toprak İşçiliği. I. Ulusal Sille Sempozyumu. Konya.

Oktaç, A. D., 2001, Konya Bağ Kültürü ve Bağ Yerleşmeleri, Selçuk Üniversitesi Fen Bilimleri Enstitüsü, Konya.

Oral, S. ve Şenbük, U., 1996, Turistik Ürünlerin Sürdürülebilir Turizm Açısından Yapısal Değerlendirilmesi, 19. Dünya Şehircilik Günü Kolokyumu, Alanya, 197-205.

Özönder, H., 1998, Sille (Tarih-Kültür- Sanat), Konya

Sarıköse, B., 2008, Osmanlı Döneminde Sille, Selçuk Üniversitesi Sosyal Bilimler Enstitüsü, Konya, 269.

Sarıköse, B., 2009, Sille Bin Yıllık Birliktelik, Konya

Selimoğlu, Ö., 2004, Dünyada ve Türkiye'de Ekoturizm, İstanbul, İstanbul Ticaret Odası Etüt ve Araştırma Şubesi

Tapur, T., 2009, Konya'da Tarihi Bir Yerleşim Merkezi: Sille, Türk Coğrafya Dergisi, 53, 14-30. 
Evaluation of Sille Settlement in the Context of Ecological

Tourizm

Tapur, T., 2014, Sillenin Coğrafik Özellikleri, I. Ulusal Sille Sempozyuтu, 177-196.

Turizm Bakanlığı, 1999, Terimler Sözlügü, Ankara

Weawer, D., 1999, Magnitude of Ekoturizm in Costa Rica and Kenya, Annals of Tourism Research, 26 (4), 792-816.

Internet resources

url1.https://www.tubitak.gov.tr/tubitak_content_files/vizyon20 23/csk/EK-13.pdf (yldiz sey) (05.05.2017)

url2.http://www.icomos.org.tr/Dosyalar/ICOMOSTR_04731720 01407841550.pdf (05.05.2017)

url3. http://www.ekoturizmdernegi.org/ (05.05.2017)

url4. http://www.gerty.ncl.ac.uk (05.05.2017)

url5.https://www.google.com.tr/search?q=sille+el+sanatlar\%C4 $\% \mathrm{~B} 1 \&$ tbm $=$ isch\&tbo $=u \&$ source $=$ univ $\&$ sa $=X \& v e d=0 a h U K$ Ewj k7eiqszUAhUF1hoKHUEC4AQsAQIJQ\&biw=1745\&bi $\underline{\mathrm{h}=895}$

\section{Resume}

A. Deniz Oktaç Beycan is an assist professor in the Department of Architecture at the Faculty of Architecture, Selcuk University.She has articles and researches on key issues of architecture, restoration and history of architecture. She has been giving lectures at the undergraduate and graduate levels at Selcuk University 